\title{
EFEKTIVITAS PENGGUNAAN LEACHET HASIL PENGURAIAN SAMPAH DALAM PROSES BIODEGRADASI LIMBAH BATIK
}

\author{
Surahma Asti Mulasari \\ Fakultas Kesehatan Masyarakat, Universitas Ahmad Dahlan, Yogyakarta
}

\begin{abstract}
Background : Treatment of textile waste industry, including batik can be implemented with a biodegradation. Biodegradation by bacteria carried either aerobic or anaerob. The bacteria are widely found in nature. On the other hand, the presence of bacteria in nature also function to decompose the waste. Own waste as a potential waste in the community. The use of environmental biotechnology is possible to simultaneously address the environmental pollution caused by waste and garbage batik. The purpose of this study was to investigate to find out the difference amount of in degrading microbial in leachet, the difference in content of organic $\mathrm{C}, \mathrm{N}$, and $P$ in leachet as a nutrient for degrading microbial growth, the effectiveness of the use leachet biodegradation in the process of batik, and to determine the effectiveness of different leachet in the biodegradation process of batik waste management.

Methods : This was quantitative study with laboratory test to determine differences in the effectiveness of the use of leachet.

Results : The content contained microbs / bacteria so that the possibility of a biological process can be implemented. There wave had of N, P, K nutrients in leachet for bacteria, waste pollution parameters decreased but didn't significantly improve the quality of batik waste.

Conclusion : There was no significant reduction the quality of batik waste.
\end{abstract}

Key words : waste, leachet, garbage, batik.

\section{PENDAHULUAN}

Sampah berpotensi sebagai limbah dalam masyarakat. Masyarakat yang hidup disekitar penimbunan sampah akan mengalami ganguan estetika dan tercemar udaranya oleh bau sampah yang menyengat. Sampah beracun dapat bersifat korosif bagi tubuh. Dekomposisi dari sampah dapat menghasilkan leachate (air lindi) dan gas yang komposisinya tergantung dari kualitas sampahnya. Leachate dapat mengotori air tanah dan menurunkan kualitas air, sedangkan gasgas yang dikeluarkan sampah dapat menimbulkan pencemaran udara. ${ }^{1}$ Salah satu hasil dari rangkaian proses dekomposisi adalah terbentuknya leachet yang berupa cairan akibat adanya air eksternal yang berinfiltrasi ke dalam timbunan sampah. Air yang ada pada timbunan sampah ini antara lain berasal dari aliran permukan yang berinfiltrasi ke dalam timbunan sampah secara horizontal melalui tempat penimbunan, kandungan air dari sampah itu sendiri, dan air hasil proses dekomposisi bahan organik dalam sampah. ${ }^{2}$

Pandangan masyarakat umum, sampah merupakan bahan yang tidak berguna dan harus disingkirkan dari lingkungan rumah mereka dan sedikit dari mereka yang menyadari adanya nilai ekonomis dari sampah yang sekiranya masih dapat dimanfaatkan. Mengingat bahwa sampai saat ini hampir semua masyarakat beranggapan bahwa sampah adalah sesuatu yang harus dibuang, maka masalah pembuangan sampah menjadi hal yang sangat penting terutama karena berkaitan dengan daya dukung lingkungan kota yang terbatas. Oleh karena itu, keberadaan. Tempat Pembuangan Sampah Akhir (TPSA) yang berada di pinggiran kota sampai 
saat ini masih menjadi solusinya. Tentu saja keberadaan TPSA tersebut mempunyai plus minus terutama bagi masyarakat yang berada di sekitar TPSA. ${ }^{3}$

Seperti umumnya TPSA, pada proses dekomposisi sampah organik akan menghasilkan gas-gas dan cairan yang disebut leachet. Leachet mengandung bahan-bahan kimia, baik organik maupun anorganik dan sejumlah bakteri patogen. Hasil survei pendahuluan di TPSA Piyungan dilakukan dengan cara menampung leachet ke dalam 7 kolam penampungan yang terdiri dari 2 kolam sedimentasi, 3 kolam aerasi dan 4 kolam maturasi (pematangan) dengan debit leachetan rata-rata dari 3 (tiga) outlet sebesar 0,16 liter per detik. ${ }^{4}$ Secara umum leachet mengandung zat organik/anorganik dengan konsentrasi tinggi, termasuk juga logam berat. ${ }^{5}$

Leachet yang dihasilkan selama proses pengolahan sampah sangat tergantung dari curah hujan di lokasi TPSA. Debit leachet maksimum yang dikeluarkan diperkirakan sekitar $408 \mathrm{~m}^{3} /$ hari dengan karakteristik senyawa organik terlarut tinggi dan senyawa anorganik seperti cloride dan kesadahan tinggi. Limbah ini akan dibuang ke Sungai Opak melalui saluran alami sejauh 1,5 km. Selama ini kondisi Sungai Opak relatif bagus, karena masih memenuhi syarat badan air golongan $\mathrm{C}$, tapi jika digunakan baku mutu golongan $\mathrm{B}$ maka kandungan COD air sungai sudah melebihi nilai baku mutunya. ${ }^{6}$ Berdasarkan observasi di lapangana masyarakat di sekitar TPSA Piyungan juga memanfaatkan leachet dari TPSA Piyungan untuk digunakan sebagai pupuk dan hasilnya memuaskan.

Selama ini terdapat sekelompok masyarakat yang menggunakan leachet dari sampah rumah tangga dan sampah hijau sebagai pupuk, yaitu di Dusun Gondolayu Lor. Gondolayu Lor adalah daerah percontohan pengelolaan sampah berbasis masyarakat. Masyarakat setempat mengolah sampah organiknya menjadi kompos. Leachet dari hasil dekomposisi sampah pada proses pengomposan tersebut digunakan sebagai pupuk cair. Bahkan, pupuk cair dari leachet tersebut dijual seharga Rp 5.000 per botol ukuran $600 \mathrm{ml}$. Pupuk ini banyak dicari petani cabai dan buah karena dapat menambah cerah warnanya. ${ }^{7}$

Potensi sebagai pupuk menunjukkan adanya aktivitas mikrobia di dalam leachet. Padahal perkembangan bioteknologi lingkungan memberikan peluang untuk memanfaatkan mikrobia sebagai biodegradator. Biodegradasi adalah pemecahan senyawa organik oleh mikrobio membentuk biomassa dan senyawa yang lebih sederhana yang akhirnya menjadi air, karbondioksida, dan metana. Proses degradasi tergantung pada mikroba meliputi: konsentrasi biomassa,keragama populasi, dan aktifitas enzim: substrat meliputi: karakteristik fisokokimia, struktur molekul, dan konsentrasi: dan faktor lingkungan meliputi: $\mathrm{pH}$, suhu, kelembapan, tersedianya akseptor elektron sebagai sumber karbon dan energi. Parameter tersebut mempengaruhi masa aklimatisasi dalam pemanfaatan substrat. Struktur molekul dan konsentrasi kontaminan mempunyai pengaruh yang sangat kuat dalam proses bioremediasi.faktor yang mempengaruhi kecepatan biodegradasi adalah tipe transformasi bakteri yang terjadi, walaupun senyawa tersebut dipakai sebagia substrat primer, sekunder atau kometabolit. ${ }^{8}$

Biodegradasi dilaksanakan oleh bakteri baik aerob ataupun anaerab. Bakteri tersebut banyak terdapat di alam. Di pihak lain, keberadaan bakteri tersebut secara alamiah berfungsi pula untuk mendekomposisi sampah. Sampah adalah bahan yang tidak mempunyai nilai atau tidak berharga untuk maksud biasa atau utama dalam pembikinan atau pemakaian barang rusak atau bercacat dalam pembikinan manufaktur atau materi berkelebihan atau ditolak atau buangan. ${ }^{9}$ Kecepatan biodegradasi dipengaruhi oleh beberapa faktor seperti konsentrasi bahan pencemar, biomassa, suhu, $\mathrm{pH}$, ketersediaan nutrien, ketersediaan substrat primer dan terjadinya adaptasi. Selain itu, komposisi bahan pencemar, kesediaan oksigen, dan kelembapan juga mempengaruhi proses biodegradasi. ${ }^{8}$

Berdasarkan hal tersebut peneliti tertarik untuk meneliti efektivitas 
penggunaan leachet sampah daun hijau sebagai biodegrator Limbah batik. Nantinya diharapkan hasil dari penelitian ini dapat mengatasi permasalahan lingkungan baik yang ditimbulkan oleh sampah ataupun oleh limbah batik.

\section{METODE PENELITIAN}

Jenis penelitian yang digunakan adalah kualitatif dengan uji laboratorium untuk mengetahui perbedaan efektivitas penggunaan leachet sebagai biodegradasi limbah batik. Menggunakan metode kualitatif karena hasil uji laboratorium dijelaskan dengan narasi untuk menguraikan perbedaan dan penyebab adanya perubahan dan tidak dianalisis secara statistik. Uji laboratoriumi dilakukan kepada leachet sampah daun hijau untuk memastikan adanya mikroorganisme dalam leachet. Pengujian dilaksanakan dengan metode plate. Uji C-organik, N, dan P leachet Leachet Sampah Daun Hijau dimaksudkan untuk menganalisis kandungan nutrisi yang dibutuhkan dalam pertumbuhan mikrobia. Parameter yang dipakai dalam pengujian limbah batik adalah BOD,COD, $\mathrm{pH}$, Phenol, TSS, Nitrat, dan warna. Setelah didapatkan data kandungan BOD,COD, pH, Phenol, TSS, Nitrat, dan warna pada pengujian limbah batik dengan menggunakan leachet sampah daun hijau dari uji laboratorium, kemudian dilakukan analisis data secara deskriptif. Sedangkan untuk kerangka konsep penelitian adalah sebagai berikut :

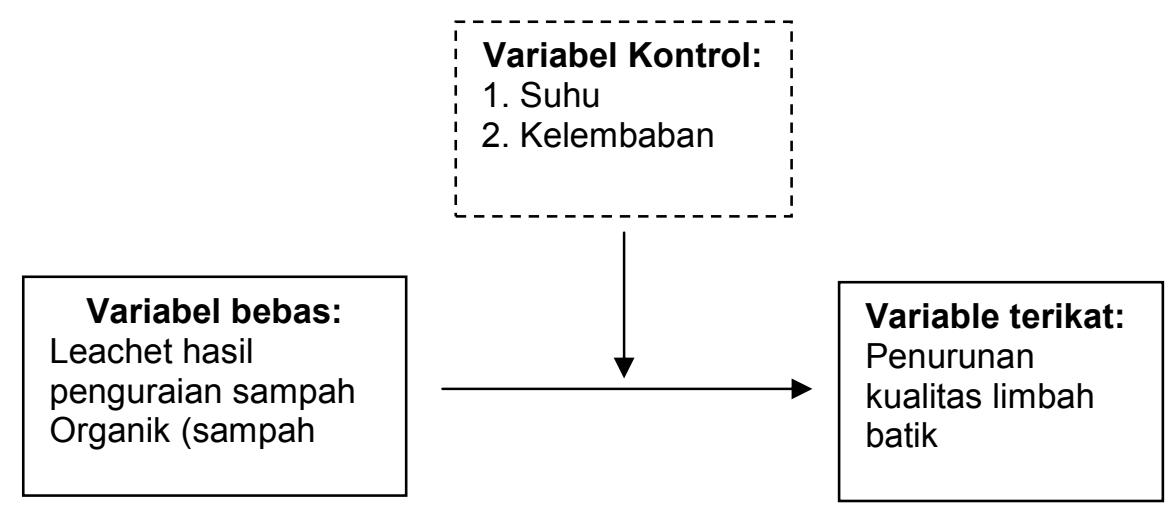

3. HASIL DAN PEMBAHASAN

\section{A. Jumlah Mikrobia Pendegradasi yang Ada dalam Leachet Hasil Penguraian Sampah}

Berdasarkan penelitian tentang adanya mikrobia dalam leachet hasil degradasi sampah didapatkan hasil sebagai berikut:

Tabel 1. Jumlah Koloni Mikrobia dalam Leachet Sampah Dapur Tahun 2011

\begin{tabular}{ccc}
\hline No. & Pengenceran & Jumlah Koloni \\
\hline 1 & $5 \mathrm{x}$ & 112 \\
\hline 2 & $4 \mathrm{x}$ & 148 \\
\hline 3 & $3 \mathrm{x}$ & 121 \\
\hline 4 & $2 \mathrm{x}$ & 910 \\
\hline
\end{tabular}


Berdasarkan tabel di atas dapat disimpulkan bahwa terdapat mikrobia yang kemungkinan sesuai jenisnya dapat digunakan sebagai pendegradasi limbah.

Mikrobia memiliki kemampuan untuk mendegradasi atau menguraikan bahan organik dan zat-zat (unsur) tertentu sehingga banyak metode yang menggunakan mikrobia untuk membantu menguraikan limbah dikenal dengan metode biologis. Pemanfaatan mikrobia, khusunya bakteri agar optimal biasanya dalam kondisi murni atau spesifik seperti dalam proses fermentasi. Proses penguraian oleh bakteri sangat tergantung dari jumlah dan jenis. Jumlah dan jenis bakteri sangat tergantung dari ketersediaan bahan organik. Bayaknya bahan organik menunjukkan jumlah makanan dan sekaligus indikasi pengotoran air limbah. Ditemukannya koloni bakteri dalam leachet sampah memberikan harapan adanya kemungkinan pemanfaatan leachet sebagai pendegradasi limbah yang lain. Uji kandungan mikrobia ini merupakan tahap awal untuk pemanfaatan mahluk hidup (mikrobia) dalam proses remidiasi.

Bioremidiasi sendiri merupakan metode pemulihan kondisi lingkungan yang tercemar oleh zat pencemar tertentu sehingga mencapai suatu acuan tertentu dengan mengggunakan cara biologi. ${ }^{8}$ Banyak penelitian yang memanfaatkan mikrobia untuk mengolah limbah baik secara langsung ataupun dengan menggunakan biomassa/lumpur aktif. Bakteri merupakan salah satu kelompok mikrobia yang mampu malaksanakan proses metabolisme bendabenda organik sehingga merupakan bagian yang terpenting dalam rantai makana dan pengolahan air limbah. Pengolahan dengan bakteri dapat terjadi dengan proses aerob dan anaerob.

Penelitian ini tidak melakukan pengujian terhadap kandungan bahan organik walaupun bahan organik adalah komponen utama untuk pertumbuhan bakteri. Hal tersebut karena dalam air limbah analisis bahan organik tidak akan menunjukkan hasil yang spesifik. Penryataan tersebut sesuai dengan pernyataan. $^{10}$

\section{B. Kandungan C-organik, N, dan P dalam Leachet Hasil Penguraian Sampah Sebagai Bahan Nutrisi Untuk Pertumbuhan Mikrobia Pendegradasi}

Hasil perhitungan N,P,K leachet sampah adalah sebagai berikut :

Tabel 2. Rerata hasil N,P,K leachet pengolahan sampah tahun 2011

\begin{tabular}{lcccc}
\hline \multicolumn{1}{c}{ Parameter } & $\mathrm{I}$ & $\mathrm{II}$ & $\mathrm{III}$ & $\Sigma$ \\
\hline $\mathrm{N}$ tot $(\%)$ & 0.09 & 0.13 & 0.09 & 0.103333 \\
\hline Ptot $(\mathrm{ppm})$ & 276.23 & 259.13 & 189.17 & 241.51 \\
\hline $\mathrm{K}$ tot $(\%)$ & 0.14 & 0.17 & 0.13 & 0.146667 \\
\hline
\end{tabular}

Berdasarkan hasil di atas dapat disimpulkan dalam leachet terdapat unsur yang dapat dipakai sebagai bahan nutrisi kehidupan bakteri. Hasil perhitungan N,P,K leachet sampah adalah sebagai disimpulkan dalam leachet terdapat unsur yang dapat dipakai sebagai bahan nutrisi kehidupan bakteri. Sampah yang menumpuk akan terdekomposisi dan akan menghasilkan cairan yang disebut lindi. Komposisi lindi sampah dipengaruhi oleh jenis dan sampah yang tertimbun, parameter kimia yang terdapat dalam sampah, mikroba yang berperan, keseimbangan air di tempat pembuangan sampah. Kandungan $\mathrm{N}, \mathrm{P}$, $\mathrm{K}$ dalam leachet ini dipergunakan sebagai indikator ketersediaan nutrisi bagi

KES MAS Vol. 6 No. 1, Januari $2012: 1$ - 74 
bakteri dalam leachet sehinnga diharapkan ketika ditambahkan ke dalam limbah batik yang kemungkinan bahan prganiknya sedikit tetap dapat bertahan hidup.

Sampah daun hijau yang hanya menggunakan daun-daun segar sebagai bahan penyusunnya. Daun hijau di dalamnya banyak terdapat unsur nitrogen, sehingga keberadaan dan melapuknya akan mendorong jasad-jasad renik aktif menguraikannya (jasad-jasad renik sendiri memerlukan nitrogen bagi perkembangannya). Bahan organik juga dapat meningkatkan daya ikat terhadap kation dan air. ${ }^{11}$

Kalium diserap dalam bentuk $\mathrm{K}^{+}$. Kalium banyak terdapat dalam sel-sel muda atau bagian tanaman yang banyak mengandung protein. Kalium berperan dalam membantu pembentukan protein dan karbohidrat, meningkatkan resistensi tanaman terhadap penyakit. Juga meningkatkan kualitas biji atau buah. ${ }^{11}$

\section{Bagaimana Efektivitas Penggunaan Leachet Hasil Penguraian Sampah dalam Proses Biodegradasi Pengelolaan Limbah Batik}

Hasil penurunan parameter limbah batik setelah diberi leachet hasil pengolahan sampah adalah sebagai berikut :

Tabel 2. Rerata Penurunan Parameter Limbah Batik Setelah Diberi Leachet Tahun 2011

\begin{tabular}{lccccc}
\hline \multicolumn{1}{c}{ Parameter } & $\mathrm{I}$ & $\mathrm{II}$ & $\mathrm{III}$ & $\mathrm{IV}$ & Baku Mutu \\
\hline BOD $(\mathrm{mg} / \mathrm{L})$ & 1357.667 & 1357 & 1254.333 & 1297 & 30 \\
\hline $\mathrm{COD}(\mathrm{mg} / \mathrm{L})$ & 3157.533 & 3179.4 & 3172 & 2149.3 & 60 \\
\hline $\mathrm{pH}$ & 7.966667 & 7.5 & 7.3 & 6.26666667 & $6 \mathrm{sd} 9$ \\
\hline PHENOL $(\mathrm{mg} / \mathrm{L})$ & 1,141 & 1,040 & 1,091 & 1,038 & 0,1 \\
\hline TSS $(\mathrm{mg} / \mathrm{L})$ & 856 & 758 & 733 & 749 & 100 \\
\hline NITRAT $(\mathrm{mg} / \mathrm{L})$ & 78.78333 & 75.81 & 73.35 & 68.3733333 & 0,06 \\
\hline warna $(\mathrm{mg} / \mathrm{L})$ & 187.3333 & 186 & 183 & 180.333333 & 50 \\
\hline
\end{tabular}

Berdasarkan tabel di atas didapatkan hasil bahwa terjadi penurunan parameter limbah batik tetapi penurunnya tidak signifikan terjadi. Bahan organik yang dibuang langsung tanpa pengolahan akan digunakan oleh bakteri untuk metabolismenya. Proses penggunaan bahan organik tersebut dilakukan dengan bantuan oksigen. Bakteri akan menggunakan oksigen untuk mengoksidasi benda-benda organik menjadi energi, bahan buangan lain, serta gas. Apabila oksigen yang tersedia tidak seimbang dengan kebutuhan bakteri, maka oksigen terlaut akan turun. Apabila oksigen dalam air sampai mencapai angka nol, maka kehidupan tidak akan terjadi di dalam air tersebut. Karena oksigen dibutuhkan untuk pernafasan oleh bakteri aerob dan kehidupan lainnya.

$\mathrm{Hal}$ tersebut di atas sesuai pernyataan Sugiharto ${ }^{10}$. Untuk mengukur kebutuhan oksigen untuk penguraian zat organik oleh bakteri dipergunakan satuan BOD (Biologycal Oxygen Demand). Semakin besar unkuran BOD menunjukan pengotoran ail limbah semakin besar. Apabila oksigen rendah maka bau-bauan berbahaya akan dihasilkan sebab unsur karbon akan berubah menjadi metan, termasuk karbondioksida, sulfur, belerang akan berubah menjadi amoniak (NH4) atau teroksidasi menjadi nitrit. 
Bakteri diperlukan untuk menguraikan bahan organik di dalam limbah. Oleh karena itu diperlukan jumlah bakteri yang cukup untuk menguraikan bahan-bahan organik tersebut. Bakteri akan berkembang biak apabila jumlah makanan yang tersedia dalam limbah tersebut cukup dan jumlah bakteri dapat dipertahankan secara konstan. Hasil penelitian menunjukkan tidak terjadi penurunan paremater secara signifikan dimungkinkan karena dalam limbah batik tersebut tidak tersedia bahan organik yang signifikan untuk pertumbuhan bakteri. Untuk optimalisasi peran bakteri dalam penguraian limbah kemungkinan diperlukan penambahan makanan bagi bakteri. Pertambahan makanan dapat berupa lumpur aktif.

Penurunan kualitas limbah tidak terlalu berarti dalam penelitian ini kemungkinan dapat disebabkan pula karena jenis bakterinya tidak cocok untuk menguraikan limbah batik. Bakteri yang tidak sesuai maka tidak akan optimal untuk menguraikan limbah. Kemungkinan yang lain adalah bakteri justru mati di dalam limbah karena limbah batik terlalu beracun dan bakteri tidak dapat tumbuh di dalam limbah batik tersebut. Limbah batik yang beracun, tidak tersedia dengan cukup bahan makanan, dan tidak cocoknya jenis bakteri untuk menguraikan limbah batik tersebut.

Hal tersebut sesuai pernyataan Sugiharto ${ }^{10}$ yang menyatakan bahwa pada awal permulaan bercampur dengan air limbah pertumbuhan bakteri akan lambat karena menyesuaiakn pertumbuhannya dengan suasana baru, keadaan ini dikenal dengan lag phase. Setelah beberapa jam berjalan maka bakteri akan tumbuh berlipat ganda dan fase ini dikenal sebagai fase akselerasi. Setelah tahap ini berakhir maka terdapat bakteri yang tetap dan bakteri yang terus meningkat jumlahnnya. Pertumbuhan yang dengan cepat setelah fase kedua ini disebut log phase. Selama log phase ini dibutuhkan jumlah makanan yang banyak, apabila jumlah makanan dan jumlah bakteri tidak dapat seimbang dikenal dengan decline phase, pada akhirnya jumlah makanan akan semakin habis dan banyak bakteri yang mati untuk menyeimbangkan dengan jumlah makanan yang dikenal sebagai phase stationary (pertumbuhan bakteri menyesuaiakan ketersediaan makanan). Setelah makanan habis maka akan terjadi di mana jumlah pertumbuhan akan lebih kecil dibandingkan dengan pertumbuhan bakteri disebut endogeneus phase, dan ketika makanan habis makan bakteri akan menggunakan cadangan energi ATP untuk aktivitasnya dan akhirnya akan mati. Untuk mempertahankan pertumbuhan bakteri diperlukan penambahan bahan makanan dari lumpur aktif. Lumpur aktif tersebut banyak mengandung makanan dan bakteri yang diperlukan.

Ketidakefektifan penurunan kualitas air limbah kemungkinan juga disebabkan karena limbah batik terlalu kompleks kandunan pencemarnya baik secara biologis, kimia ataupun fisika. Limbah yang begitu kompleks tidak efektif untuk hnaya diturunkan kualitasnya dengan metode biologis saja, dalam penelitian ini menggunakan leachet hasil pengolahan sampah. Kekomplekan limbah batik kemungkinan seharusnya diolah dengan intergrasi antara pengolahan biologis, kimia, dan fisik. 


\section{SIMPULAN DAN SARAN}

\section{A. Simpulan}

1) Terdapat mikrobia pendegradasi dalam leachet hasil penguraian sampah.

2) Ada kandungan C-organik, $N$, dan $P$ dalam leachet hasil penguraian sampah sebagai bahan nutrisi untuk pertumbuhan mikrobia pendegradasi.

3) Penggunaan leachet hasil penguraian sampah dalam proses biodegradasi pengelolaan limbah batik tidak menurunkan secara drastis.

\section{B. Saran}

1) Untuk penelitian selanjutnya, ibutuhkan identifikasi mikrobia secara spesifik sehingga dapat dibuat kultur murni yang dapat digunakan secara khusus untuk mendegradasi limbah batik.

2) Untuk memberikan hasil yang signifikan perlu dilakukan penelitian dengan memberi tambahan nutrien untuk meningkatkan optimalisasi kerja bakteri sehingga jumlah bakteri meningkat dan dapat meningkatkan efektifitas pengolahan limbah.

3) Untuk memberikan hasil yang signifikan perlu dilakukan penelitian dengan penambahan waktu atau penambahan kadar leachet sehingga dapat lebih optimal menurunkan parameter pencemaran.

4) Perlu penelitian lanjutan untuk mengkolaborasikan pengolahan secara biologi,kimia, dan fisika agar pengolahan limbah dapat lebih spesifik.

\section{DAFTAR PUSTAKA}

1. Slamet, J.S., Kesehatan Lingkungan, Gadjah Mada University Press., Yogyakarta. 2004

2. Purwanto, A., Penurunan $\mathrm{BOD}, \mathrm{COD}, \mathrm{CO}_{2}$, dan SS Leachate Tempat Pembuangan Akhir Sampah Dengan Perlakuan Penanaman Enceng Gondok (Eichornia Crassipes (Mart.) Solms), Skripsi, STL, Yogyakarta. 1997

3. Aminatun, T., Plus Minus Keberadaan Tempat Pembuangan Akhir (TPA) Bagi Masyarakat di Sekitarnya (Studi Kasus di TPA Piyungan Yogyakarta), Institusi Teknologi Adhi Tama Surabaya, Surabaya. 2003

4. Joko, dan Ganefati, Pengolahan Lindian (Leachate) TPA Piyungan Sebagai Upaya Pencegahan Pencemaran Sungai Opak Yogyakarta : http://www.w3.org/TR/html4/ loose.dtd, diambil pada tanggal 19 Januari 2007, Yogyakarta. 2001

5. Korah, N.N., Kajian Kualitas Leachate Di Bekas TPA Tambakboyo, Air Sumur dan Air Sungai Di Sekitarnya, Skripsi, STTL, Yogyakarta. 1997

6. Dinas Pekerjaan Umum Propinsi Yogyakarta, Laporan Analisis Dampak Lingkungan, Yogyakarta. 1995

7. Mulasari, Inovasi masyarakat Dalam Swakelola Sampah Gondolayu Lor Propinsi Daerah Istimewa Yogyakarta, Laporan Penelitian, Fakultas Kesehatan Masyarakat. Universitas Ahmad Dahlan, Yogyakarta. 2008

8. Fahruddin, Bioteknologi Lingkungan, Penerbit Alfabeta, Bandung. 2010

9. Ismoyo, I.H. dan Rijaluzzaman, Kamus Istilah lingkungan, Bina Rena Pariwara, Jakarta. 1994

10. Sugiharto, Dasar-dasar Pengelolaan Air Limbah, Penerbit Universitas Indonesia. 1987

11. Sutejo, M.M., Pupuk dan Cara Pemupukan, Penerbit Rineka Cipta, Jakarta. 2002 